\title{
New Normal Policy: Promosi Kebijakan Pariwisata Dalam Rangka Percepatan Penanganan Dampak Covid-19
}

\author{
Sri Utami1, Janianton Damanik², Dyah Mutiarin*3 \\ Universitas Gajah Mada, Indonesia \\ Email: mutiarin@umy.ac.id
}

\begin{abstract}
Covid 19 raises uncertainty and constant changes so that the need for information in the form of government policies is very important to be conveyed to the public. This paper describes government policies in tourism, namely: the mitigation and recovery program for the tourism sector during the new normal transition period in order to accelerate the handling of the impact of Covid-19. This government policy is conveyed to the public through the Ministry of Tourism and Creative Economy's official social media accounts, one of which is the official Twitter account @Kemenparekraf. To determine the suitability of the policies prepared and submitted to the public, a qualitative content analysis (QCA) was carried out on the @Kemenparekraf account, using NVivo12 with features including the management, word frequency analysis, and informal data visualization. Of the 807 (eight hundred and seven) tweets of the @Kemenparekraf account posted from June to December 2020, there are only 3 (three) hashtags / words that can directly explain the policy, namely \#banggabuatanindonesia for Anugerah Bangga Buatan Indonesia 2020 (BBI) activity, \#indonesiacare for InDOnesia CARE Certification (I Do Care), and chse for CHSE Support (Cleanliness, Health, Safety, Environment). The use of hashtags / words in tweets still does not explain the overall policy. This research can be continued by comparing targets, program outputs and their impact on tourism actors and the creative economy.
\end{abstract}

Keywords: Covid 19; change; government policies in tourism; official twitter accounts, the qualitative content analysis (QCA)

\begin{abstract}
Abstrak
Covid 19 memunculkan ketidakpastian dan perubahan yang sangat konstan sehingga kebutuhan informasi berupa kebijakan pemerintah menjadi sangat penting untuk disampaikan kepada masyarakat. Dalam makalah ini dideskripsikan mengenai kebijakan pemerintah bidang pariwisata, yaitu: program mitigasi dan pemulihan sektor pariwisata pada masa transisi kenormalan baru dalam rangka percepatan penanganan dampak covid-19. Kebijakan pemerintah tersebut disampaikan kepada masyarakat melalui akun media sosial official Kemenparekraf, salah satunya adalah akun twitter official @Kemenparekraf. Untuk mengetahui sejauh mana kesesuaian kebijakan yang disusun dan yang disampaikan kepada masyarakat, dilakukan qualitative content analysis (QCA) terhadap akun @Kemenparekraf, menggunakan NVivo12 dengan fitur antara lain the management, word frequency analysis, dan visualisasi data informal. Dari 807 (delapan ratus tujuh) tweet akun @Kemenparekraf yang diposting sejak Juni s.d Desember 2020, hanya terdapat 3 (tiga) hashtag/kata yang dapat langsung menjelaskan kebijakan., yaitu \#banggabuatanindonesia untuk kegiatan Anugerah Bangga Buatan Indonesia (BBI) 2020, \#indonesiacare untuk Sertifikasi InDOnesia CARE (I Do Care), dan chse untuk Dukungan CHSE (Cleanliness, Health, Safety, Environment). Penggunaan hashtag/kata dalam tweet masih belum dapat menjelaskan kebijakan secara keseluruhan. Penelitian ini dapat dilanjutkan dengan membandingkan target, output program dan dampaknya kepada pelaku pariwisata dan ekonomi kreatif.
\end{abstract}

Kata Kunci: Covid 19; perubahan; kebijakan pemerintah bidang pariwisata; akun twitter official qualitative content analysis (QCA)

* Corresponding author 


\section{A. PENDAHULUAN}

Covid-19 pertama kali ditemukan di Wuhan, Provinsi Hubei, Tiongkok pada Desember 2019, kemudian menyebar ke beberapa negara di dunia termasuk Indonesia (Soehardi \& Untari, 2020). Pada 3 Maret 2020, Indonesia telah mengumumkan kasus pertama COVID-19 di Jakarta. Jumlah kasus terus meningkat setiap harinya. Penyebaran COVID-19 secara bertahap terutama disebabkan oleh aktivitas masyarakat, meskipun telah ditetapkan kebijakan social distancing dan penghapusan aktivitas yang memicu keramaian. Pemerintah Indonesia menetapkan keadaan darurat kesehatan melalui Keputusan Presiden Nomor 11 Tahun 2020 tentang Penetapan Penyakit Virus Corona Darurat Kesehatan Masyarakat, kebijakan ini menunjukkan bahwa keadaan darurat dibutuhkan di seluruh wilayah Indonesia (Loilatu, J, M., 2021) dan per tanggal 31 Maret 2020 mulai diberlakukan kebijakan pembatasan sosial berskala besar melalui peraturan pemerintah Nomor 21 Tahun 2020 tentang Pembatasan Sosial Berskala Besar dalam rangka Percepatan Penanganan Corona Virus Disease 2019 (Covid-19) sebagai upaya mencegah penyebaran virus. Covid-19 bergerak cepat menginfeksi 713.365 orang dan merenggut 21.237 nyawa pada 28 Desember 2020, menjadi salah satu pandemi global terburuk (Worldometers, 2020).

Covid-19 adalah masalah global, dengan kondisi ekonomi dunia yang hampir macet (Açikgöz \& Günay, 2020). Pandemi Coronavirus telah menyebabkan pembatasan pergerakan dan penutupan tempat kerja (Williams \& Kayaoglu, 2020). Covid-19 berdampak besar hampir di semua aspek kehidupan termasuk sektor pariwisata karena meningkatnya pembatasan perjalanan, pembatalan acara besar dan keengganan untuk melakukan perjalanan internasional dan domestik (Sugihamretha, 2020). Pandemi COVID-19 telah menghabiskan sekitar Rp 85 triliun (US \$ 5,87 miliar) dari pendapatan pariwisata Indonesia sepanjang tahun ini. Industri hotel dan restoran telah kehilangan pendapatan hampir Rp 70 triliun karena perjalanan liburan benarbenar terhenti. Lebih dari 95 persen pekerja di sektor pariwisata diberhentikan tanpa dibayar, 2.000 hotel dan 8.000 restoran ditutup selama tiga bulan pertama wabah (Haryadi dalam Akhlas, 2020).

Kebijakan United Nation World Tourism Organization (UNWTO) untuk mendukung pekerjaan dan ekonomi melalui perjalanan dan pariwisata mencakup seruan tindakan untuk mengurangi dampak sosial-ekonomi Covid-19 dan untuk mempercepat pemulihan, pertama diterbitkan pada April 2020. Kebijakan tersebut meliputi 3 (tiga) strategi yaitu: mengelola krisis dan memitigasi dampak, memberikan stimulus \& mempercepat pemulihan, dan mempersiapkan hari esok (Collins-Kreiner \& Ram, 2020). Ketika negara-negara pulih dari puncak pertama pandemi COVID19, pendekatan yang terkoordinasi dan bersumber daya yang tepat untuk rehabilitasi untuk fase pemulihan sangat penting, untuk mengelola konsekuensi jangka panjang dari infeksi COVID19 dan untuk memulihkan fungsi yang hilang sebagai akibat dari efek tidak langsung dari respons pandemi (de Biase et al., 2020).

Pandemi dan penyakit baru, telah lama memiliki efek transformasional pada lingkungan dan masyarakat. Tindakan transformasional dan kemungkinan pandemi modern bukanlah hal baru (Vuolo et al., 2020). Dalam lanskap pariwisata pasca-COVID, membangun minat dan membangkitkan emosi positif terhadap produk pariwisata sangat penting untuk pemulihan destinasi (Yung et al., 2020). Citra destinasi cukup banyak sebagai tempat yang aman dan terjamin di mana pelancong akan merasa lebih baik (Van et al., 2020). Pemerintah Indonesia menetapkan masa transisi kenormalan baru pada awal Juni 2020 (Anies, dalam Setyawan 2020). Pemerintah memanfaatkan kesempatan tersebut, untuk membangun minat dan membangkitkan emosi positif terhadap produk pariwisata. Beberapa kebijakan untuk mencapai target devisa USD 
21 miliar yang sebelumnya disusun pada tahun 2019 diubah guna pemulihan destinasi pasca pandemi covid-19 dan disampaikan kepada masyarakat melalui media sosial (Kemenparekraf, 2020).

Djalante et al., (2020) mengemukakan bahwa pemerintah Indonesia perlu langkah strategis untuk merespon pemberantasan wabah COVID-19 dengan membuat sebuah rekomendasi peraturan dan sistem kelembagaan kuat, termasuk pembentukan satuan tugas untuk penanganan COVID-19. Persiapan pemerintah pusat dalam menangani wabah COVID-19 setidaknya telah mengeluarkan beberapa kebijakan dalam kurun waktu sejak pertama kemunculan kasus pertama di Indonesia. Seperti social distancing, physic distancing, learn from home, work from home, beribadah di rumah, menggunakan alat pelindung diri (APD), cuci tangan, dan lain-lain (Putri \& Anulus, 2020; Zaharah et al., 2020). Penyebaran virus mengakibatkan perubahan pola hidup masyarakat dan tidak siap untuk beradaptasi (Zaharah et al., 2020). Di samping itu, pemerintah Indonesia sampai sekarang belum menerapkan kebijakan lock-down sebagaimana negara-negara lain, Indonesia hanya menerapkan pembatasan sosial berskala besar (Calvin, 2020). Bersamaan dengan implementasi kebijakan untuk mencegah dan memitigasi COVID-19, konflik muncul di tengah-tengah pandemi yang bersumber dari kebijakan pemerintah pusat dan lokal (Ansori, 2020), untuk mencegah hal tersebut pemerintah perlu meningkatkan koordinasi dan mengeluarkan kebijakan yang tepat (Djalante et al., 2020).

Covid 19 memunculkan ketidakpastian dan perubahan yang sangat konstan sehingga kebutuhan informasi menjadi sangat penting. Informasi yang dimaksud tidak hanya dari sisi kuantitas namun juga dari sisi kualitas (Falcone \& Sapienza, 2020). Kebijakan pemerintah yang diubah karena covid-19, harus segera diinformasikan kepada masyarakat dan pemangku kepentingan. Informasi tersebut dapat memberi rasa aman bagi masyarakat dalam hal perlindungan dari virus, penghentian penyebarannya (Gorfinkel et al., 2020) dan memungkinkan untuk membuat kondisi lebih dapat diprediksi (Falcone \& Sapienza, 2020).

Media sosial memberikan kesempatan unik dan luar biasa kepada sektor publik untuk mempromosikannya kebijakan dan kegiatan, mengirim pesan untuk berinteraksi dengan warga (Hancu-Budui et al., 2020). Media sosial sebagai alat informasi yang memfasilitasi pihak berwenang untuk memberikan informasi dengan mengidentifikasi tempat kejadian dan mentransfer informasi secara real-time (Bonsón et al., 2019). Sebagai salah satu platform media sosial, twitter yang merupakan website media sosial miniblogging yang gratis dengan 152 juta pengguna harian, apabila digunakan untuk menyampaikan informasi content kebijakan resmi dari pemerintah, menjadikan twitter sebagai alat yang ampuh bagi pemimpin dunia untuk berkomunikasi dengan cepat dengan warga selama pandemi (Rufai \& Bunce, 2020). Informasi yang disampaikan dengan cepat tersebut, dapat menghindari trust gap masyarakat terhadap pemerintah. Bagaimana masyarakat menggunakan informasi dan menjadi faham, adalah peluang media bagi pemerintah untuk mempromosikan kebijakan secara lebih luas dan lebih seimbang (Falcone \& Sapienza, 2020), sehingga selanjutnya pemerintah dapat mempromosikan citra destinasi dengan efektif (de las Heras-Pedrosa et al., 2020).

Berdasarkan latar belakang diatas, pada makalah ini akan dibahas mengenai kebijakan nasional Pemerintah Indonesia bidang pariwisata guna dalam rangka percepatan penanganan dampak covid-19 pada masa transisi kenormalan baru dan kesesuaian antara kebijakan yang disusun dengan yang disampaikan kepada masyarakat menggunakan media sosial twitter official Kemenparekraf. 


\section{B. METODE PENELITIAN}

Penelitian ini menggunakan metode penelitian kualitatif deskriptif (Sugiyono, 2019) dan kualitatif analisis data dengan menggunakan bantuan program komputer Nvivo 12 Plus (Brandão, 2015; Loilatu et al, 2020). Pengumpulan data dilakukan dengan studi data kebijakan dari Kementerian Pariwisata dan Ekonomi Kreatif tahun anggaran 2020 dalam rangka percepatan penanganan dampak covid-19 dan menangkap data dari akun twitter official Kementerian Pariwisata dan Ekonomi Kreatif dengan menggunakan NCapture google, sejak Juni s.d Desember 2020. Analisis data kualitatif deskriptif dilakukan dengan tahapan reduksi data, display data, dan penarikan kesimpulan/verifikasi (Miles and Huberman, 2008; Sugiyono, 2019). Sedangkan untuk analisis data kuantitatif dilakukan dengan tahapan membuat project, mempersiapkan dokumen, coding data, dan analisis (AlYahmady \& Al Abri, 2013; Loilatu et al, 2020). Untuk menterjemahkan data yang tidak terstuktur digunakan qualitative content analysis (QCA) (Kaefer, Roper, \& Sinha, 2015, Loilatu et al, 2020).

Pada makalah ini akan dibahas mengenai 1) Bagaimana kebijakan nasional Pemerintah Indonesia bidang pariwisata pada masa transisi kenormalan baru, guna percepatan penanganan dampak covid19?, 2) Bagaimana kesesuaian antara kebijakan yang disusun dan yang disampaikan melalui media sosial akun twitter official Kemenparekraf?.

\section{HASIL DAN ANALISIS}

\section{Kebijakan Bidang Pariwisata}

Penyebaran Covid 19 yang begitu masif berdampak signifikan terhadap pariwisata nasional maupun internasional. UNWTO memperkirakan akan terjadi penurunan kedatangan wisatawan internasional sebesar 58\% hingga 78\% pada tahun 2020 dibandingkan dengan tahun 2019. Pandemi Covid 19 yang melanda Indonesia menyebabkan Pemerintah Indonesia dalam hal ini Kemenparekraf (Kementerian Pariwisata dan Ekonomi Kreatif) menyesuaikan kembali target kinerja bidang pariwisata tahun 2020 yang sebelumnya sudah ditetapkan dalam RPJMN (Rencana Pembangunan Jangka Menengah Nasional) (Kemenparekraf, 2020), yang meliputi:

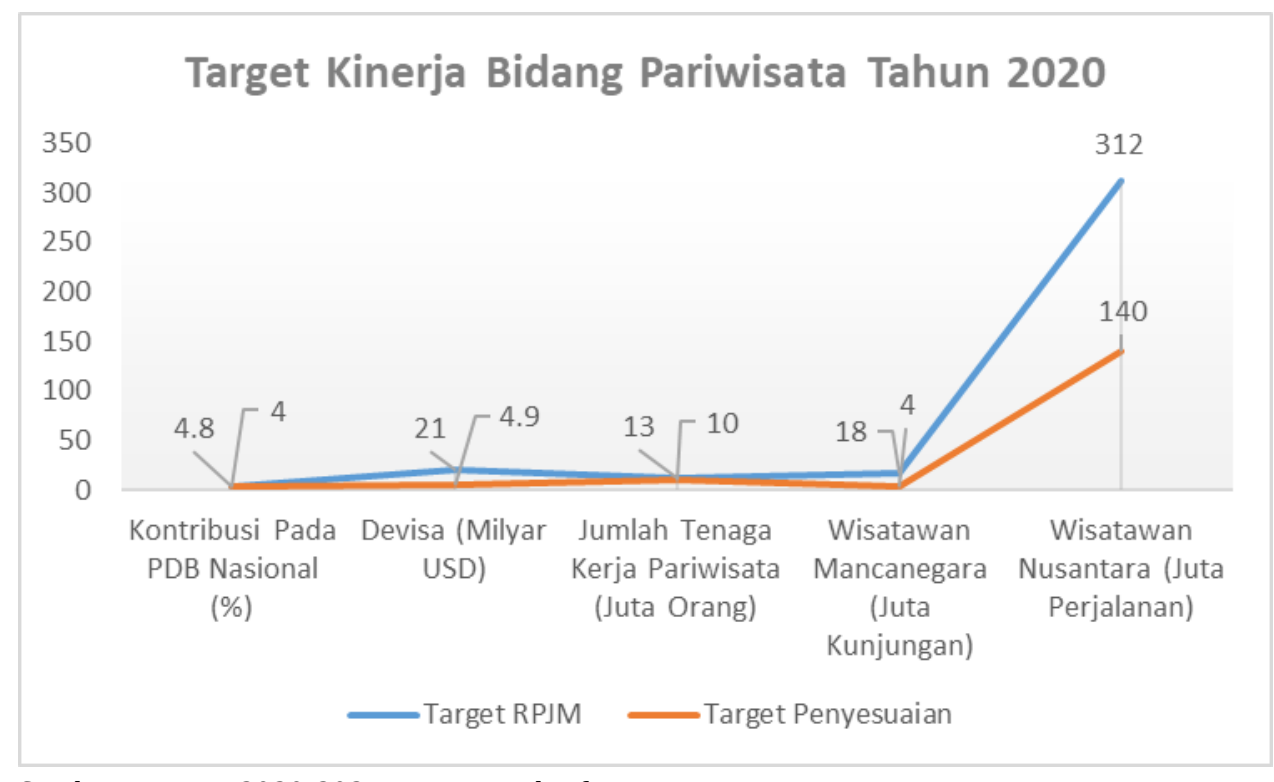

Sumber: Renstra 2020-2024 Kemenparekraf

Gambar 1. Target Kinerja Bidang Pariwisata Tahun 2020 
Target kinerja dalam rencana strategis Kemenparekraf merupakan target kinerja indikatif, dan indikator diatas merupakan sebagian dari indikator kinerja Kemenparekraf lainnya. Untuk tahun 2020, kontribusi pada PDB, devisi, jumlah tenaga kerja pariwisata, jumlah wisatawan mancanegara dan wisatawan nusantara diperkirakan turun. Perkiraan target jumlah wisatawan mancanegara turun 350\% (dari 18 juta kunjungan target RPJMN menjadi 4 juta kunjungan setelah disesuaikan), yang berdampak pada turunnya devisa dari USD 21 Milyar menjadi USD 3,3 - 4,9 Milyar. Target jumlah wisatawan nusantara juga ikut diturunkan 123\% (dari 312 juta perjalanan menjadi 120-140 juta perjalanan), jumlah tenaga kerja pariwisata diturunkan 30\% (dari 13 juta orang menjadi 10 juta orang), dan kontribusi pariwisata terhadap PDB Nasional diturunkan 20\% (dari 4.8\% menjadi 4\%) (Kemenparekraf, 2020).

Penurunan target kinerja bidang pariwisata diatas merupakan dampak dari pandemi terhadap sektor pariwisata dan ekonomi kreatif yang telah mengakibatkan kerugian. Untuk jumlah kunjungan wisatawan mancanegara, dikaitkan dengan larangan perjalanan internasional menyebabkan semakin melemahnya pasar pariwisata internasional. Pembatalan kedatangan ribuan turis ke destinasi liburan populer di Indonesia, menimbulkan kerugian mencapai triliunan rupiah. Hanya 70 penerbangan beroperasi dari 79.000 penerbangan sebelum pandemi, 87\% pernurunan kunjungan wisatawan asing, dan $67 \%$ penurunan tingkat hunian hotel secara keseluruhan (Kemenparekraf, 2020).

Selanjutnya pandemi menjadi sebab destinasi wisata harus ditutup. Kebijakan tersebut ditetapkan sebagai langkah untuk melindungi masyarakat, mengendalikan mobilitas serta kegiatan masyarakat, dan antisipasi lonjakan kasus covid 19 (Anies dalam CNN Indonesia 2020). Provinsi yang paling banyak menutup destinasi wisatanya adalah Jawa tengah (71 destinasi), dan penutupan destinasi paling lama di Kep. Riau yaitu s.d 7 April 2020 (Kemenparekraf, 2020). Identifikasi penutupan destinasi obyek wisata, tempat hiburan, tempat rekreasi, industri pariwisata di wilayah destinasi regional I (Aceh, Sumatera Utara, Riau, Kep. Riau, Sumatera Barat, Bengkulu, Jambi, Sumatera Selatan, Bangka Belitung, Lampung, Banten, DKI Jakarta, Jawa Barat, Jawa Tengah, D.I Yogyakarta, dan Jawa Timur) selama pandemi, dapat dilihat pada tabel berikut:

Tabel 1. Identifikasi Penutupan Destinasi Obyek Wisata, Tempat Hiburan, Tempat Rekreasi, Industri Pariwisata di Wilayan Destinasi Regional I

\begin{tabular}{ccc}
\hline Provinsi & $\begin{array}{c}\text { Jumlah Kab/Kota yang menutup } \\
\text { obyek wisata }\end{array}$ & Masa Penutupan \\
\hline Aceh & $3 \mathrm{Kab} /$ Kota & $16-31$ Maret 2020 \\
\hline Sumatera Utara & $12 \mathrm{Kab} /$ Kota & 23 Maret - 3 April 2020 \\
\hline Riau & $4 \mathrm{Kab} /$ Kota & $16-31$ Maret 2020 \\
\hline Kep. Riau & $5 \mathrm{Kab} /$ Kota & 23 Maret - 7 April 2020 \\
\hline Sumatera Barat & $17 \mathrm{Kab} /$ Kota & $23-31$ Maret 2020 \\
\hline Bengkulu & $3 \mathrm{Kab} /$ Kota & $16-31$ Maret 2020 \\
\hline Jambi & $5 \mathrm{Kab} /$ Kota & $16-29$ Maret 2020 \\
\hline Sumatera Selatan & $3 \mathrm{Kab} /$ Kota & $18-31$ Maret 2020 \\
\hline Bangka Belitung & $5 \mathrm{Kab} /$ Kota & $18-31$ Maret 2020 \\
\hline Lampung & $2 \mathrm{Kab} /$ Kota & 19 Maret - 3 April 2020 \\
\hline Banten & $7 \mathrm{Kab} /$ Kota & $18-31$ Maret 2020 \\
\hline DKI Jakarta & 23 destinasi & 14 Maret - 3 April 2020 \\
\hline Jawa Barat & 21 Kab/Kota & $13-31$ Maret 2020 \\
\hline Jawa Tengah & 71 destinasi & $14-31$ Maret 2020 \\
\hline
\end{tabular}

24 Jurnal Kepariwisataan: Destinasi, Hospitalitas dan Perjalanan, Volume 5 Nomor 1, 2021: 20-33 


\begin{tabular}{ccc}
\hline D.I Yogyakarta & 37 destinasi & $16-31$ Maret 2020 \\
\hline Jawa Timur & 21 Kab/Kota & $19-31$ Maret 2020 \\
\hline
\end{tabular}

Sumber: Kemenparekraf, 2020

Dalam rangka mengatasi dampak pandemi, pemerintah Indonesia melakukan Refocussing Kegiatan, Realokasi Anggaran, Serta Pengadaan Barang dan Jasa Dalam Rangka Percepatan Penanganan Corona Virus Disease 2019 (Covid-19), sebagai dasar pelaksanaan hal tersebut, Presiden Jokowi mengeluarkan Instruksi Presiden Nomor 4 tahun 2020 tanggal 20 Maret 2020 (Sekretariat Kabinet, 2020), dan selanjutnya Menteri Keuangan mengeluarkan Surat Edaran Menteri Keuangan Nomor SE-6/MK.02/2020 tanggal 15 Maret 2020 (Kementerian Keuangan, 2020). Pada Bidang Pariwisata, Menteri Pariwisata dan Ekonomi Kreatif menerbitkan Instruksi Menteri Pariwisata dan Ekonomi Kreatif Nomor 1 tahun 2020 tanggal 23 Maret 2020 tentang Pelaksanaan Refocussing Kegiatan, Realokasi Anggaran, Serta Pengadaan Barang dan Jasa Dalam Rangka Percepatan Penanganan Corona Virus Disease 2019 (Covid-19) (Kemeparekraf, 2020).

Langkah-langkah mitigasi arahan Presiden Jokowi di bidang pariwisata agar sektor pariwisata dan ekonomi kreatif serta para pekerjanya dapat bertahan di tengah pandemi, yaitu 1) Program Perlindungan Sosial bagi pekerja di sektor pariwisata, 2) Realokasi Anggaran Kemenparekraf ke program padat karya bagi pekerja yang bergerak di bidang pariwisata, 3) Stimulus ekomomi bagi para pelaku usaha pariwisata dan ekonomi kreatif agar tidak terjadi PHK secara besar-besaran (Kemenparekraf, 2020). Langkah mitigasi tersebut dituangkan dalam program dan kegiatan sebagaimana tabel 2 berikut:

Tabel 2. Program Mitigasi Dampak Pandemi

\begin{tabular}{ll}
\hline \multicolumn{1}{c}{ Program } & \multicolumn{1}{c}{ Kegiatan } \\
\hline Program Perlindungan Sosial & Dukungan Industri Pariwisata untuk Nakes, Program BaLaSa \\
& (Bahan Pokok dan Lauk Siap Saji), Koordinasi dengan \\
& Kementerian Lembaga lainnya (Program Pra Kerja, Bansos \\
& Kemensos) \\
\hline Padat Karya & Gerakan BISA (Bersih Indah Sehat dan Aman), Pembuatan \\
& Konten, Gerakan \& Ajakan Masyarakat, Koordinasi dengan \\
& Kementerian lainnya (Program Padat Karya Desa untuk Desa \\
& Wisata) \\
\hline Program Stimulus & Virtual Events, Webinar/Online Training, dan Bantuan Model \\
& Bisnis, Kebijakan Fiskal dan Moneter: Relaksasi Pajak dsb \\
\hline
\end{tabular}

Sumber: Kemenparekraf, 2020

Transisi ke arah kenormalan yang diterapkan mulai awal Juni 2020 dengan tetap memperhatikan penurunan kasus Covid-19 di beberapa daerah, menyebabkan aktivitas pariwisata perlahan mulai ditingkatkan. Hotel, tempat wisata, restoran, dan transportasi mulai dibuka (CollinsKreiner \& Ram, 2020). Sebagai dukungan dari pemerintah terhadap industri pariwisata dan ekonomi kreatif, beberapa program diselenggarakan di daerah dengan tetap berkoordinasi dengan pemerintah setempat dan disiplin menjalankan kebijakan protokol kesehatan. Pemerintah 1) menyediakan fasilitas akomodasi, transportasi dan konsumsi bagi tenaga medis dan tenaga pendukung RS Rujukan penanganan Covid-19 (\#JagaSesama) sesuai rekomendasi Gugus Tugas Percepatan Penanganan Covid-19, 2) menggerakkan pelaku UMKM di sektor parekraf (\#JagaProduktivitas) untuk berpartisipasi dalam kampanye: \#GerakanMaskerKain yang melibatkan UMKM sektor ekraf untuk membuat 1 juta masker kain secara nasional, \#GerakanLaukSiapSaji yang melibatkan UMKM sektor ekraf di daerah untuk menyiapkan makanan bagi masyarakat yang terdampak, \#SatuDalamKopi 
sebagai kampanye upaya bersama memajukan kopi, 3) melakukan kampanye \#JagaJarak (\#JagaKomunikasi), menggandeng pelaku ekonomi kreatif melalui media komunikasi, 4) menyelenggarakan pelatihan online gratis (\#JagaKreativitas), untuk upskilling dan reskilling pelaku pariwisata dan ekonomi kreatif, 5) menyusun rencana mitigasi terhadap sektor parekraf (\#JagaOptimisme), program-program yang dapat membantu keberlangsungan pendapatan dan peningkatan kualitas destinasi serta usaha sektor parekraf, dan 6) membuat usulan lapangan usaha (\#JagaUpaya) sektor parerkaf untuk masuk ke dalam Permenkeu 23/0MK.03/2020 sehingga pelaku parekraf mendapatkan insentif berupa subsidi PPh21, Pembebasan PPh 22 Impor, dan pengurangan PPh sebesar 30 persen (Kemenparekraf, 2020).

Pemerintah juga merancang program dan kegiatan pemulihan sektor pariwisata dan ekonomi kreatif dengan membangun keseimbangan antara penyediaan (supply) dan permintaan (demand), yang meliputi tabel 4:

Tabel 4. Program dan Kegiatan Pemulihan Sektor Pariwisata

\begin{tabular}{llllll}
\hline & Program & Kegiatan \\
\hline Supply & Persiapan Destinasi Wisata & Dukungan & CHSE & (Cleanliness, Health, Safety,
\end{tabular}
Environment) di DTW: Komponen Kebersihan, Kesehatan, Keamanan, Lingkungan, Penguatan Sapta Pesona Di Daya Tarik Wisata, Revitalisasi, Amenitas Di Daya Tarik Wisata, dan Bimtek 3A (Atraksi, Amenitas Dan Aksesibilitas). Peningkatan Sarana di Destinasi: Bioskop Misbar, Greenhouse, dan Creative Hub

Implementasi dan Monitoring Panduan protokol kesehatan tersebut terdiri dari Protokol CHSE di daerah pedoman protokol kesehatan di Daya Tarik Wisata, Persiapan Destinasi Homestay/Pondok Wisata, Hotel, Panduan MICE, Penyelenggaraan Kegiatan (Event), Restoran/Rumah Makan, Wisata Arung Jeram, Wisata Golf, dan Wisata Selam. Sertifikasi protokol kebersihan, kesehatan, keselamatan, kelestarian lingkungan ini dinamakan InDOnesia CARE (I Do Care)

\begin{tabular}{ll}
\hline Inovasi Pelaku Event di Fase & At-home-concert \#DiRumahAja (Konser Good \\
Tanggap Darurat Covid-19: & Vibrations Bersama Jaga Indonesia, Good \\
Penyelenggaraan Virtual \& & Vibrations), Virtual Tour, Drive-in-concert (Konser \\
Hybrid Events, & New Live Experience) \\
\hline Peningkatan Kualitas SDM & Pelatihan hybrid (online dan offine) dan sertifikasi \\
Parekraf & SDM parekraf \\
\hline Peningkatan Kuantitas Dan & Baparekraf Digital Talent, Baparekraf For Startup, \\
Kualitas Produk Kreatif & Scene, Capture, Bedah Desain Kemasan Kuliner \\
& Nusantara (Beda'kan), Bedah Gerai Kuliner \\
& (Begerak), Aksi, Selaras dan Sinergi (Aksilarasi) \\
\hline dan Kreatif Dari Rumah \\
\hline Membangun Infrastruktur & Peningkatan Akses Pembiayaan di Bidang Kuliner, \\
Konektivitas yang Kompetitif & Fesyen, Kriya, Aplikasi, Pengembang Permainan, \\
dengan Negara Lain, dan & Film, Animasi dan Video, Pariwisata (sektor \\
\hline
\end{tabular}

26 Jurnal Kepariwisataan: Destinasi, Hospitalitas dan Perjalanan, Volume 5 Nomor 1, 2021: 20-33 


\begin{tabular}{|c|c|c|}
\hline & Hibah Pariwisata & $\begin{array}{l}\text { pariwisata khusus untuk usaha Homestay dan } \\
\text { Usaha Wisata yang berada di Desa Wisata). Hibah } \\
\text { Pariwisata, dan Bantuan Insentif Pemerintah } \\
\text { Penambahan Modal Kerja untuk meningkatkan } \\
\text { kapasitas usaha/produksi pelaku usaha pariwisata } \\
\text { dan ekonomi kreatif }\end{array}$ \\
\hline \multirow[t]{2}{*}{ Demand } & $\begin{array}{l}\text { Membangun Citra yang } \\
\text { Menciptakan Rasa Aman dan } \\
\text { Nyaman \& Menarik Minat } \\
\text { Pasar }\end{array}$ & $\begin{array}{l}\text { Membangun Citra yang Menciptakan Rasa Aman } \\
\text { dan Nyaman \& Menarik Minat Pasar dan } \\
\text { Menjadikan Indonesia sebagai Destinasi Utama di } \\
\text { Asia PasifikPengembangan Kapasitas melalui } \\
\text { Komunikasi \& Campaign, Kemitraan, Key Opinion } \\
\text { Leader (KOL) dan Live Streaming dan Sales Mission. } \\
\text { Digital Aset (Meningkatkan Omset Melalui } \\
\text { Optimalisasi Digital Aset), Marketplace (Promosi \& } \\
\text { Penjualan Melalui Gojel, Grab, Shope, Tokopedia, } \\
\text { Bluebird, Bukalapak, Blibli.Com, JD.id, Lazada), } \\
\text { Pendampingan (Training, Consulting, Mentoring, } \\
\text { dan Coaching) dan Anugerah Bangga Buatan } \\
\text { Indonesia (BBI) } 2020\end{array}$ \\
\hline & $\begin{array}{l}\text { Pemberian Insentif/Paket, } \\
\text { Optimalisasi Kegiatan MICE } \\
\text { K/L di Destinasi Wisata, } \\
\text { Insentif Peningkatan Daya Beli } \\
\text { Produk Lokal, dan } \\
\text { Memperluas dan } \\
\text { Memperbesar Konektivitas } \\
\text { Wisatawan } \\
\text { Pengembangan Produk Wisata } \\
\text { dan Penyelenggara Kegiatan } \\
\text { (Events) }\end{array}$ & $\begin{array}{l}\text { Pengembangan Kapasitas Profesional Industri } \\
\text { MICE, Aktivitas Promosi MICE Bekerjasama dengan } \\
\text { Kementerian/Lembaga, Pemerintah Daerah \& } \\
\text { Korporasi, Fasilitasi Bidding MICE Internasional } \\
\text { Untuk Dilaksanakan Di Indonesia dan Pembuatan } \\
\text { Platform MICE.Id }\end{array}$ \\
\hline
\end{tabular}

Sumber: Kemenparekraf, 2020

Merujuk kepada kebijakan yang direkomendasikan oleh UNWTO yang meliputi strategi mengelola krisis dan memitigasi dampak, memberikan stimulus \& mempercepat pemulihan, dan mempersiapkan hari esok (Collins-Kreiner \& Ram, 2020), pemerintah Indonesia telah menyusun kebijakan program mitigasi dan pemulihan sektor pariwisata yang meliputi program perlindungan sosial bagi pekerja di sektor pariwisata, program padat karya bagi pekerja yang bergerak di bidang pariwisata dan stimulus ekomomi bagi para pelaku usaha pariwisata dan ekonomi kreatif.

Untuk membangun minat dan membangkitkan emosi positif terhadap produk wisata (Yung et al., 2020) dan mengembalikan citra destinasi sebagai tempat yang aman dan terjamin bagi pelancong (Van et al., 2020) pasca pandemi, pada masa transisi kenormalan baru pemerintah Indonesia mengeluarkan kebijakan untuk mempersiapkan destinasi wisata melalui peningkatan sarana di destinasi, menyusun protokol kesehatan/protokol CHSE, memonitoring implementasi protokol CHSE di destinasi melalui sertifikasi I Do Care. Dan sebagai upaya peningkatan atraksi di destinasi diselenggarakan virtual \& Hybrid Events, destinasi juga mulai dipromosikan kembali melalui campaign, Key Opinion Leader (KOL), dan Sales Mission. 


\section{Qualitative Content Analysis (QCA)}

Untuk menganalisa kesesuaian antara kebijakan pemerintah bidang pariwisata yang disusun dan disampaikan kepada masyarakat melalui media sosial twitter, digunakan qualitative content analysis (QCA) (Kaefer, Roper, \& Sinha, 2015, Loilatu et al, 2020) terhadap akun twitter official @Kemenparekraf. Tahapan yang dilakukan dalam proses QCA adalah 1) mendownload data tweet dari akun @Kemenparekraf mulai dari Juni s.d Desember 2020 menggunakan Aplikasi NCapture google (pada tahapan ini diperoleh data dengan tipe data *.nvc), 2) data nvc tersebut diimport ke dalam Aplikasi Nvivo, 3) untuk memperoleh data kata-kata yang paling sering muncul, dilakukan analysis content dengan cara query word frequency terhadap data hasil import dari NCapture, 5) dilakukan visualisasi terhadap data hasil query word frequency.

Dari tahapan diatas, diperoleh frekuensi informasi yang disampaikan oleh akun @Kemenparekraf melalui jumlah tweet sebanyak sebanyak 807 (delapan ratus tujuh) tweet. Jumlah tweet terbanyak terjadi pada bulan Oktober sejumlah 141 (seratus empat puluh satu) tweet dan bulan Agustus sejumlah 140 (seratus empat puluh) tweet. Dan untuk periode per minggu, paling banyak 37 (tiga puluh tujuh) tweet ditweet pada periode 22/06/2020 - 28/06/2020 dan 05/10/2020 11/10/2020 dan paling sedikit 5 (lima) tweet ditweet pada periode 01/06/2020 - 07/06/2020 dan 28/12/2020 - 29/12/2020. Frekuensi informasi secara detail dapat diliat pada grafik berikut:

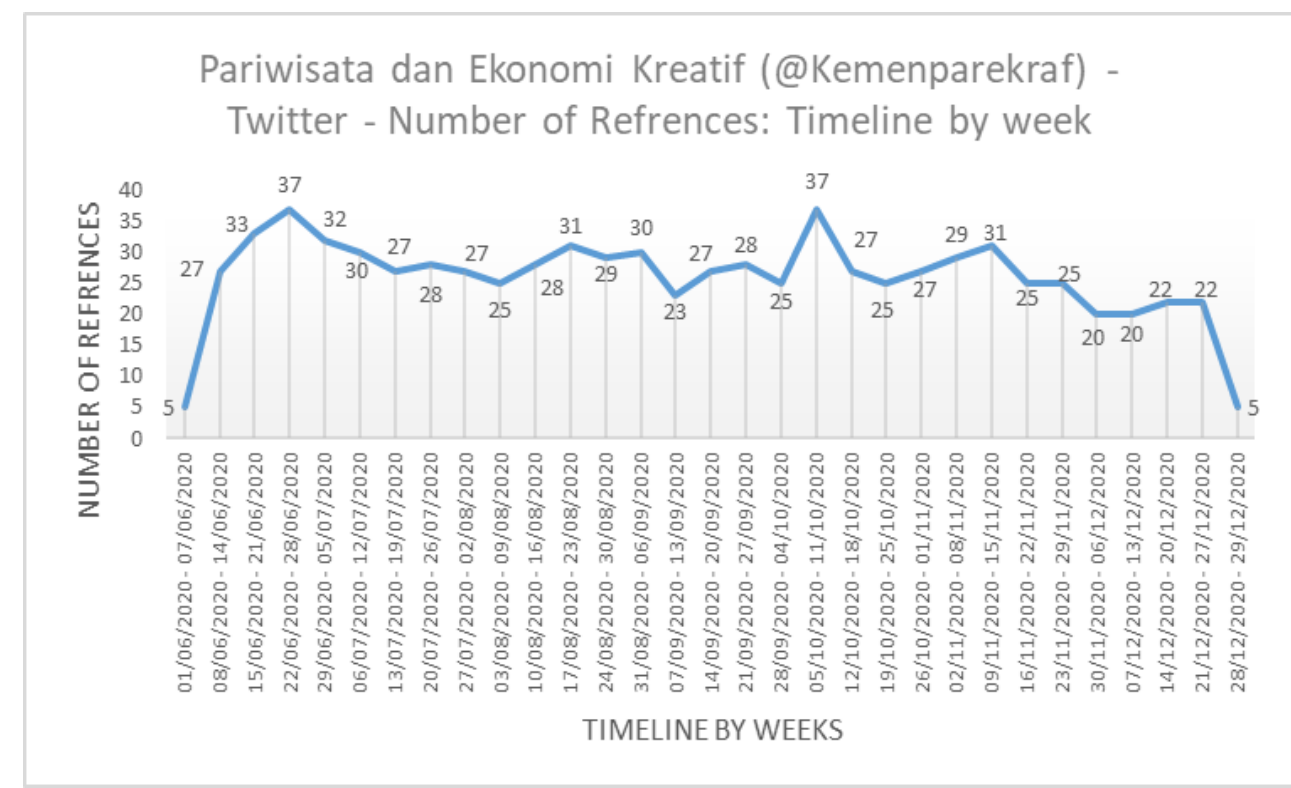

Sumber: Olahan data tweet dari Nvivo

Gambar 2. Jumlah tweet per minggu (Juni s.d Desember 2020)

Karakter informasi selama masa transisi kenormalan baru diidentifikasi dengan hashtag yang paling sering digunakan akun @Kemenparekraf. Hashtag, digunakan oleh pengguna twitter untuk mengatur tweet. Hashtag membantu lebih mudah ditemukannya subject daripada mencari dengan teks lengkap dari suatu tweet tertentu. Semua informasi terkait acara yang sama dapat diberi tag dengan cara yang sama dan diumumkan (Chang, 2010). Hashtag memberikan cara mudah kepada audiens untuk mendeteksi konten tertentu melalui topik dan forum yang menarik bagi mereka. Hashtag yang bersifat jangka pendek, berlangsung musiman untuk kepentingan peluncuran suatu produk baru atau kemitraan disebut Campaign hashtag (Solomia Fedushko, Yuriy Syerov, 2019). Karakter informasi melalui hashtag dari akun @Kemenparekraf, dapat dilihat pada gambar 3 berikut: 


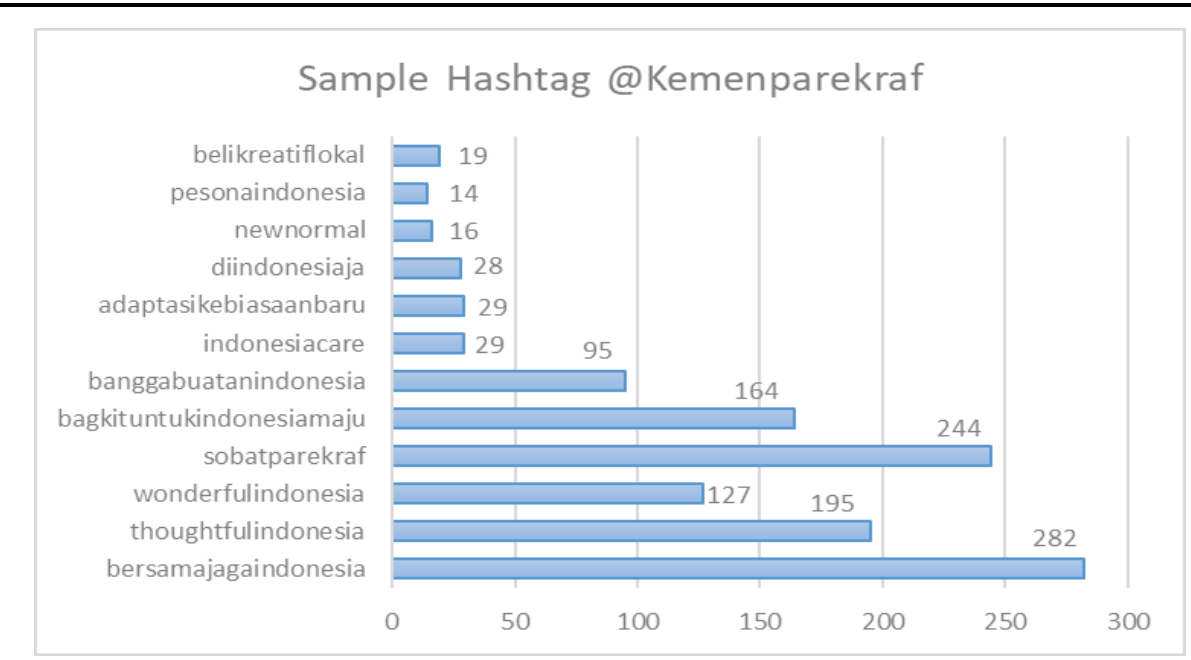

Sumber: Olahan data hashtag dari Nvivo

Gambar 3. Sample Hashtag @Kemenparekraf (Juni s.d Desember 2020)

Hashtag yang paling banyak digunakan oleh Akun twitter @Kemenparekraf dalam kurun waktu Juni s.d 29 Desember 2020 adalah: \#bersamajagaindonesia (282), \#sobatparekraf (244), \#thoughfulindonesia (195), \#bangkituntukindonesiamaju (164) dan \#wonderfulindonesia (127). Hasil persandingan hashtag yang digunakan oleh Kemenparekraf sebagai bagian dari nomenklatur kebijakan dan yang disampaikan kepada masyarakat melalui akun twitter @Kemenparekraf tidak ada yang sesuai dan dapat menjelaskan kebijakan (level kegiatan) secara langsung. Namun apabila dikaitkan, terdapat hashtag yang mendukung promosi kebijakan, diantaranya adalah \#belikreatiflokal, \#newnormal, \#diindonesiaja, \#adaptasikebiasaanbaru, \#indonesiacare, \#banggabuatanindonesia, dan \#bangkituntukindonesiamaju.

Untuk mendukung hasil temuan diatas, selanjutnya dilakukan filter kata-kata yang terkait topik yang diteliti dan memiliki frekuensi penggunaan tertinggi yang digunakan oleh akun twitter @Kemenparekraf melalui word frequency analysis. Word frequeuncy analysis akan menganalisis suatu konten secara lebih spesifik berdasarkan kode tertentu yang sederhana. Word frequency analysys akan memberikan daftar kata seinklusif mungkin tanpa banyak modifikasi untuk menghindari bias (Dicle \& Dicle, 2018). Hasil word frequency analysis akun @Kemenparekraf, sebagaimana di gambar 4 berikut:

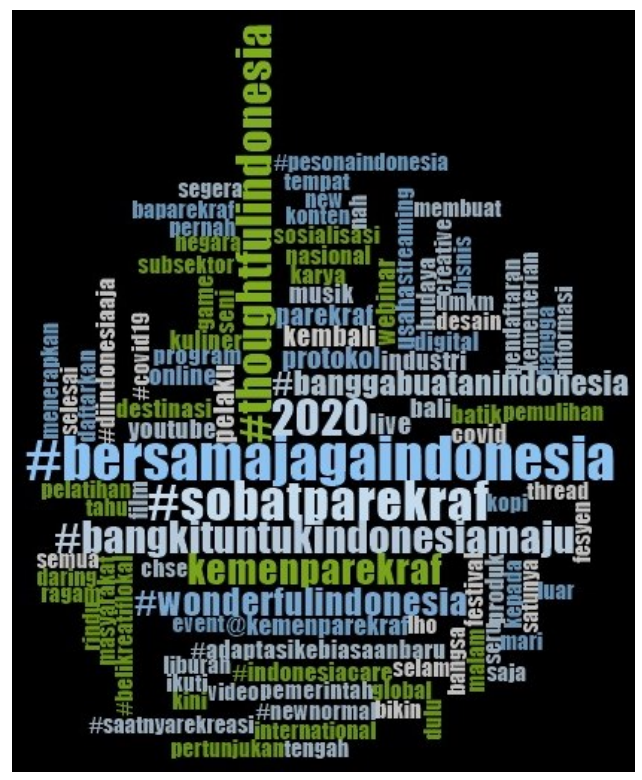

Gambar 4. Word Cloud Offical Akun @Kemenparekraf 
Frekuensi kata yang paling sering digunakan adalah \#bersamajagaindonesia, \#sobatparekraf, \#thoughtfulIndonesia, \#bangkituntukIndonesiamaju. Dari 52 (lima puluh dua) kata yang berfrekuensi sering digunakan oleh akun @Kemenparekraf terdapat 22 (dua puluh dua) kata yang digunakan dalam 13 (tiga belas) kegiatan yang merupakan bagian dari kebijakan bidang pariwisata dalam rangka Percepatan Penanganan Corona Virus Disease 2019 (Covid-19). Dari 22 (dua puluh dua) kata tersebut, hanya 3 (tiga) yang dapat langsung menjelaskan tentang kebijakan, yaitu: \#banggabuatanindonesia, \#indonesiacare dan chse.

Informasi content kebijakan resmi dari pemerintah (Rufai \& Bunce, 2020) dan dalam rangka promosi kebijakan melalui media sosial (Hancu-Budui et al., 2020) di bidang pariwisata telah disampaikan oleh pemerintah Indonesia melalui akun twitter @Kemenparekraf. Namun dari hasil temuan dalam penelitian, penggunaan akun @Kemenparekraf belum maksimal. Hanya 3 (tiga) hashtag/kata yang dapat langsung menjelaskan kebijakan yang telah disusun oleh pemerintah., yaitu \#banggabuatanindonesia untuk kegiatan Anugerah Bangga Buatan Indonesia (BBI) 2020, \#indonesiacare untuk Sertifikasi InDOnesia CARE (I Do Care), dan chse untuk Dukungan CHSE (Cleanliness, Health, Safety, Environment). Dan terdapat 1 (satu) kata yang sering digunakan yang memiliki makna hampir sama dengan nomenklatur kebijakan yaitu program online untuk menjelaskan kegiatan pelatihan online atau kegiatan online lainnya.

\section{SIMPULAN}

Kebijakan pemerintah bidang pariwisata mengadopsi rekomendasi strategi yang disampaikan oleh UNWTO, yaitu: program mitigasi dan pemulihan sektor pariwisata meliputi program perlindungan sosial bagi pekerja di sektor pariwisata, program padat karya bagi pekerja yang bergerak di bidang pariwisata dan stimulus ekomomi bagi para pelaku usaha pariwisata dan ekonomi kreatif. Kebijakan diatas disampaikan kepada masyarakat melalui akun twitter official @Kemenparekraf. Namun penggunaan hashtag/kata dalam tweet masih belum dapat menjelaskan kebijakan secara keseluruhan.

Batasan penelitian ini masih terbatas pada penjelasan mengenai kebijakan, program dan kegiatan pemerintah bidang pariwisata pada masa transisi kenormalan baru, serta kesesuaian antara kebijakan yang disusun dan yang disampaikan melalui akun twitter @Kemenparekraf, penelitian berikutnya dapat dilanjutkan dengan membandingkan target, output program dan dampaknya kepada pelaku pariwisata dan ekonomi kreatif.

\section{DAFTAR REFERENSI}

\section{Artikel}

Açikgöz, Ö., \& Günay, A. (2020). The early impact of the Covid-19 pandemic on the global and Turkish economy. Turkish Journal of Medical Sciences, 50(SI-1), 520-526. https://doi.org/10.3906/sag2004-6

Ansori, M. H. (2020). Assessing and Mitigating Conflicts amidst the COVID-19 Pandemic in Indonesia. The Insights, 16(4).

Bonsón, E., Perea, D., \& Bednárová, M. (2019). Twitter as a tool for citizen engagement: An empirical study of the Andalusian municipalities. Government Information Quarterly, 36(3), 480-489. https://doi.org/10.1016/j.giq.2019.03.001

Calvin. (2020). Handling Covid-19 Related To Regional Security According To Asean Political-Security Community. Lex Scientia Law Review, 4(1), 19-32.

https://doi.org/https://doi.org/10.15294/lesrev.v4i1.38195

Chang, H. C. (2010). A new perspective on Twitter hashtag use: Diffusion of innovation theory. Proceedings of the ASIST Annual Meeting, 47(November 2010). https://doi.org/10.1002/meet.14504701295

30 Jurnal Kepariwisataan: Destinasi, Hospitalitas dan Perjalanan, Volume 5 Nomor 1, 2021: 20-33 
Collins-Kreiner, N., \& Ram, Y. (2020). National tourism strategies during the Covid-19 pandemic. Annals of Tourism Research, хxхx, 103076. https://doi.org/10.1016/j.annals.2020.103076

de Biase, S., Cook, L., Skelton, D. A., Witham, M., \& ten Hove, R. (2020). The COVID-19 rehabilitation pandemic. Age and Ageing, 49(5), 696-700. https://doi.org/10.1093/ageing/afaa118

Dicle, M. F., \& Dicle, B. (2018). Content Analysis: Frequency Distribution of Words. SSRN Electronic Journal, October. https://doi.org/10.2139/ssrn.2997101

Djalante, R., Lassa, J., Setiamarga, D., Sudjatma, A., Indrawan, M., Haryanto, B., Mahfud, C., Sinapoy, M. S., Djalante, S., Rafliana, I., Gunawan, L. A., Surtiari, G. A. K., \& Warsilah, H. (2020). Review and analysis of current responses to COVID-19 in Indonesia: Period of January to March 2020. Progress in Disaster Science, 6, 100091. https://doi.org/10.1016/j.pdisas.2020.100091

Falcone, R., \& Sapienza, A. (2020). How COVID-19 changed the information needs of Italian citizens. International Journal of Environmental Research and Public Health, 17(19), 1-19. https://doi.org/10.3390/ijerph17196988

Gorfinkel, L., Muscat, T., Ollerhead, S., \& Chik, A. (2020). The role of government's 'Owned Media' in fostering cultural inclusion: a case study of the NSW Department of Education's online and social media during COVID-19. Media International Australia, 2019. https://doi.org/10.1177/1329878X20968291

Hancu-Budui, A., Zorio-Grima, A., \& Blanco-Vega, J. (2020). Audit institutions in the European Union: Public service promotion, environmental engagement and COVID crisis communication through social media. Sustainability (Switzerland), 12(23), 1-32. https://doi.org/10.3390/su12239816

Loilatu, J, M., et al. (2021). How Public Transportation Use Social Media Platform during Covid-19: Study on Jakarta Public Transportations ' Twitter Accounts ? 18(1), 1-19. https://doi.org/10.14704/WEB/V18I1/WEB18001

Putri, S. I., \& Anulus, A. (2020). Preventive actions to minimizing the coronavirus disease 19 ( COVID19 ) transmissions among health workers : a systematic review. Journal of the Medical Sciences, 52(3), 110-119. https://doi.org/http://dx.doi.org/10.19106/JMedSciSI005203202012

Rufai, S. R., \& Bunce, C. (2020). World leaders' usage of twitter in response to the COVID-19 pandemic: A content analysis. Journal of Public Health (United Kingdom), 42(3), 510-516. https://doi.org/10.1093/pubmed/fdaa049

Soehardi, S., \& Untari, D. T. (2020). The Effect of Covid-19 Pandemic on Hotel Employees, Hotel Occopancy Rates and Hotel Tax Income in Jakarta, Indonesia. Systematic Reviews in Pharmacy, 11(12), 964-972. https://doi.org/10.31838/srp.2020.5.138

Solomia Fedushko,Yuriy Syerov, and S. K. (2019). Hashtag as a Way of Archiving and Distributing.pdf. https://www.researchgate.net/publication/335172961\%0D

Van, N. T. T., Vrana, V., Duy, N. T., Minh, D. X. H., Dzung, P. T., Mondal, S. R., \& Das, S. (2020). The role of human-machine interactive devices for post-COVID-19 innovative sustainable tourism in Ho Chi Minh City, Vietnam. Sustainability (Switzerland), 12(22), 1-30. https://doi.org/10.3390/su12229523

Vuolo, M., Kelly, B. C., \& Roscigno, V. J. (2020). COVID-19 Mask Requirements as a Workers' Rights Issue: Parallels to Smoking Bans. American Journal of Preventive Medicine, 59(5), 764-767. https://doi.org/10.1016/j.amepre.2020.07.001

Williams, C. C., \& Kayaoglu, A. (2020). COVID-19 and undeclared work: impacts and policy responses in Europe. Service Industries Journal, 40(13-14), 914-931. https://doi.org/10.1080/02642069.2020.1757073 
Yung, R., Khoo-Lattimore, C., \& Potter, L. E. (2020). Virtual reality and tourism marketing: conceptualizing a framework on presence, emotion, and intention. Current Issues in Tourism, $0(0)$, 1-21. https://doi.org/10.1080/13683500.2020.1820454

Zaharah, Kirilova, G. I., \& Windarti, A. (2020). Impact of Corona Virus Outbreak Towards Teaching and Learning Activities in Indonesia. Jurnal Sosial \& Budaya Syar-I, 7(3), 269-282. https://doi.org/10.15408/sjsbs.v7i3.15104

\section{Buku}

Kemenparekraf. (2020). Rencana Strategis Kemenparekraf/Baparekraf 2020-2024. Kemenparekraf.

Kemenparekraf. (2020). Inmen Parekraf Nomor 1 tahun 2020 tanggal 23 Maret 2020 tentang Pelaksanaan Refocussing Kegiatan, Realokasi Anggaran, Serta Pengadaan Barang dan Jasa Dalam Rangka Percepatan Penanganan Corona Virus Disease 2019 (Covid-19). Kemenparekraf.

Kemenparekraf. (2020). Program Dukungan Kemenparekraf Dalam Rangka 2020 Percepatan Penanganan Corona Virus Disease 2019 (Covid-19). Kemenparekaf.

Kementerian Keuangan. (2020). Surat Edaran Menteri Keuangan Nomor SE-6/MK.02/2020 tanggal 15 Maret 2020 tentang Refocussing Kegiatan Realokasi Anggaran Serta Pengadaan Barang Dan Jasa. Kemenkeu.

Sekretariat Kabinet. (2020). Instruksi Presiden Nomor 4 tahun 2020 tanggal 20 Maret 2020 tentang Refocussing Kegiatan Realokasi Anggaran Serta Pengadaan Barang Dan Jasa. Setkab RI.

Sugiono. (2019). Metode Penelitian Pariwisata (Kuantitatif, Kualitatif, Kombinasi R\&D). Alfabeta Bandung.

\section{Internet}

Akhlas, A, W. (2020). Pandemic erases $\$ 5.9 \mathrm{~b}$ of Indonesia's tourism revenue as businesses seek help. The Jakarta Post.

Retrieved from https://www.thejakartapost.com/news/2020/07/14/pandemic-erases-5-9b-of-indonesiastourism-revenue-as-businesses-seek-help.html.

CNN Indonesia. (2020). Cegah Covid, DKI Tutup 20 Tempat Wisata Hingga Tahun Baru. CNN Indonesia.

Retrieved from https://www.cnnindonesia.com/nasional/20201223185821-20-585830/cegah-covid-dkitutup-20-tempat-wisata-hingga-tahun-baru

Kemenparekraf. (2020). Arahan Presiden Jokowi : Mitigasi Dampak Covid-19 Untuk Sektor Parekraf. Kemenparekraf.

Retrieved from https://pedulicovid19.kemenparekraf.go.id/arahan-presiden-jokowi-mitigasi-dampakcovid-19-untuk-sektor-parekraf/

Kemenparekraf. (2020). Program Kemenparekraf Dalam Menanggulangi Covid-19. Kemenparekraf.

Retrieved from https://pedulicovid19.kemenparekraf.go.id/program-kemenparekraf-dalampenanggulangan-covid-19-2/

Kemenparekraf. (2020). Peta Penutupan Destinasi Wisata di Indonesia. Kemenparekraf.

32 Jurnal Kepariwisataan: Destinasi, Hospitalitas dan Perjalanan, Volume 5 Nomor 1, 2021: 20-33 


\section{Retrieved from}

https://pedulicovid19.kemenparekraf.go.id/peta-penutupan-destinasi-wisata-di-indonesia/ Setyawan. (2020). Anies Perpanjang PSBB Jakarta, Juni Jadi Masa Transisi. CCN Indonesia

Retrieved from

https://www.cnnindonesia.com/nasional/20200603155954-20-509512/anies-perpanjangpsbb-jakarta-juni-jadi-masa-transisi.

Worldometer. (2020). COVID-19 CORONAVIRUS PANDEMIC. Worldmeter

Retrieved from

https://www.worldometers.info/coronavirus/. 